\title{
The nutritive quality of cholla cactus as affected by burning
}

\author{
J.E. SAWYER, L.A. KNOX, G.B. DONART, AND M.K. PETERSEN
}

Authors are extension beef specialist and assistant professor, Animal and Range Sciences Department, New Mexico State University, Las Cruces, N.M. 88003; agent, Texas Agricultural Extension Service; professor of Range Science, New Mexico State University, Las Cruces, N.M. 88003; and professor of Animal Science, New Mexico State University, Las Cruces, N.M. 88003.

\section{Abstract}

Cholla cactus may serve as an emergency feedstuff for livestock when forage availability is low. A study was conducted at the Corona Range and Livestock Research Center to evaluate the nutritive quality of cholla cactus (Opuntia imbricata) after spine removal. Six samples were collected for each treatment in a completely randomized design. Treatments consisted of spine removal by burning with a propane torch (BURN), or leaving spines intact (UN). Each sample consisted of 2 burned and 2 unburned cladodes from each of 5 plants. One sample from each treatment was weighed immediately after collection and used solely for dry matter (DM) determination. Remaining samples were evaluated for crude protein (CP), organic matter (OM), neutral detergent fiber (NDF), and mineral composition. Rate and extent of ruminal DM and OM disappearance were estimated in situ for 20 and 68 hours in the rumen of each of 2 cannulated cows grazing native rangeland. Dry matter contents of burned and unburned cholla were $12.7 \%$ and $12.4 \%$ respectively. Crude protein was not affected by burning $(P>0.6 ; 13.0 \% \mathrm{UN}, 13.6 \%$ BURN, SE \pm 0.7$)$. Burning reduced OM $(82.4 \% \mathrm{UN}, 81.0 \%$ BURN; SE \pm 0.4$)$ and NDF (48.6\% UN, 39.2\% BURN; SE \pm 1.8$)$ content $(P<0.03)$. Reduced NDF contributed to increased rate and extent of ruminal OM disappearance for burned cholla (P < 0.03). Mineral content was minimally affected by burning. Measurements indicate that cholla has relatively high nutrient quality, but the high moisture content would require large amounts to be fed as an emergency feed source.

Key Words: drought forages, mineral content, emergency feeding

Drought is a frequent and recurring situation on western rangelands. A major problem created by drought is depletion of quantity and quality of forage available for livestock. Dormant forage is often limiting in both total and available crude protein (Krysl et al. 1987) and the lack of new forage growth combined with continued forage demand may create a shortage of grazeable forage. This situation must be addressed by removal of livestock, provision of emergency feedstuffs, or some combination thereof.

Characteristics of ideal emergency feedstuffs include adequate nutritive quality to meet realistic production goals, abundant and available supplies, and minimal cost. Hay and grains may not contain an adequate nutrient balance to meet animal requirements; additionally, these sources may be in short supply or prohibitively expensive during drought situations. An alternative to these "traditional" emergency feeds is the feeding of cactus.

Manuscript accepted 17 Aug. 2000.

\section{Resumen}

La "Cholla" una especie cactácea puede servir como alimento de emergencia para el ganado cuando la disponibilidad de forraje es baja. En el Centro Corona de Investigación en Pastizales y Ganado se condujo un estudio para evaluar la calidad nutritiva de la "Cholla" (Opuntia imbrincata) después de remover las espinas. Se colectaron 6 muestras por tratamiento bajo un diseño completamente al azar. Los tratamientos consistieron en: 1) la remoción de la espina con fuego utilizando un soplete de gas propano (quema) y 2) dejando intactas las espinas (sin quema). Cada muestra consistió de 2 cladodios quemados y 2 sin quemar colectados en 5 plantas. Una muestra de cada tratamiento se pesó inmediatamente después de colectada y fue utilizada únicamente para determinar materia seca (MS). En las muestras restantes se determinó la proteína cruda $(\mathrm{PC})$, materia orgánica (MO), fibra neutro detergente (FND) y la composición mineral. La tasa y cantidad de desaparición ruminal de la materia orgánica y materia seca se estimo in situ a las 20 y $68 \mathrm{~h}$, la estimación se realizó en el rumen de cada una de 2 vacas canuladas apacentando pastizal nativo. Los contenidos de MS de la "Cholla" quemada y sin quemar fueron $12.7 \%$ y $12.4 \%$ respectivamente. La proteína cruda se afectó por la quema $(P>0.6 ; 13.0 \%$ sin quema, $13.6 \%$ con quema $\mathrm{SE} \pm 0.7)$. La quema redujo el contenido de MO $(82.4 \%$ sin quema; $81.0 \%$ con quema $\mathrm{SE} \pm 0.4)$ y la FND (48.6\% sin quema y $39.2 \%$ con quema $S E \pm 0.7)$. El bajo contenido de FND contribuyó a aumentar la tasa y cantidad de desaparición de la MO de la "Cholla" quemada (P < 0.03). El contenido mineral fue afectado minimamente por la quema. Las mediciones indican que la "Cholla" tiene una calidad nutritiva relativamente alta, pero por su alto contenido de humedad se requerirían grandes cantidades para ser una fuente de alimento de emergencia.

Cactus has been used as an emergency feedstuff for many years (Griffiths and Hare 1906; Wooten 1911) and may meet the criteria of availability on rangelands where large stands of cacti exist. Providing cactus as an emergency feed may be less expensive than feeding hay (Hanselka and Paschal 1990). Most reports have concentrated on prickly pear cactus, and little current information is available on the nutritive quality of cholla cactus, which is more abundant than prickly pear on central New Mexico rangelands (Pieper et al. 1974). Early reports concerning the feeding of cacti describe both burning and chopping as methods of provision (Griffiths and Hare 1906, Thornber 1911). Therefore, the objectives of this study were to describe the nutritive quality of cholla cactus during a drought, and to evaluate the effects of burning on measures of nutritive quality. 


\section{Materials and Methods}

\section{Study Area}

The experiment was conducted at New Mexico State University's Corona Range and Livestock Research Center located 15 $\mathrm{km}$ east of Corona (Lat $34.26^{\circ} \mathrm{N}$, Long $\left.105.41^{\circ} \mathrm{W}\right)$. Elevation at the site is $1900 \mathrm{~m}$ and average annual precipitation is 400 $\mathrm{mm}$ with a majority occurring during the summer months as brief but intense convectional thunderstorms. Total precipitation from June 1994 through May 1996 (i.e., the 24 months preceding sampling) was $518 \mathrm{~mm}$ (Fig. 1). Average precipitation over this time span is $794 \mathrm{~mm}$ (Krysl et al., 1987), so that only $65 \%$ of normal precipitation had been received during this period. Major forage species include blue grama (Bouteloua gracilis (H.B.K.) Lag. Ex Steud.) and wolftail (Lycurus phleoides H.B.K.) with minor components of other species. Walkingstick cholla (Opuntia imbricata (Haw.) D.C.) can be an important part of the plant community, sometimes forming dense stands.

\section{Sampling Methods}

Sampling was conducted during June 1996. This sampling time occurred after a long period of below average precipitation, and is reflective of drought conditions under which cholla would likely be utilized as a feedstuff. A transect was marked in a randomly chosen direction across a large stand of cholla. The cholla in this stand ranged from $30 \mathrm{~cm}$ to $200 \mathrm{~cm}$ in height. Plants were from $1 \mathrm{~m}$ to $5 \mathrm{~m}$ apart.

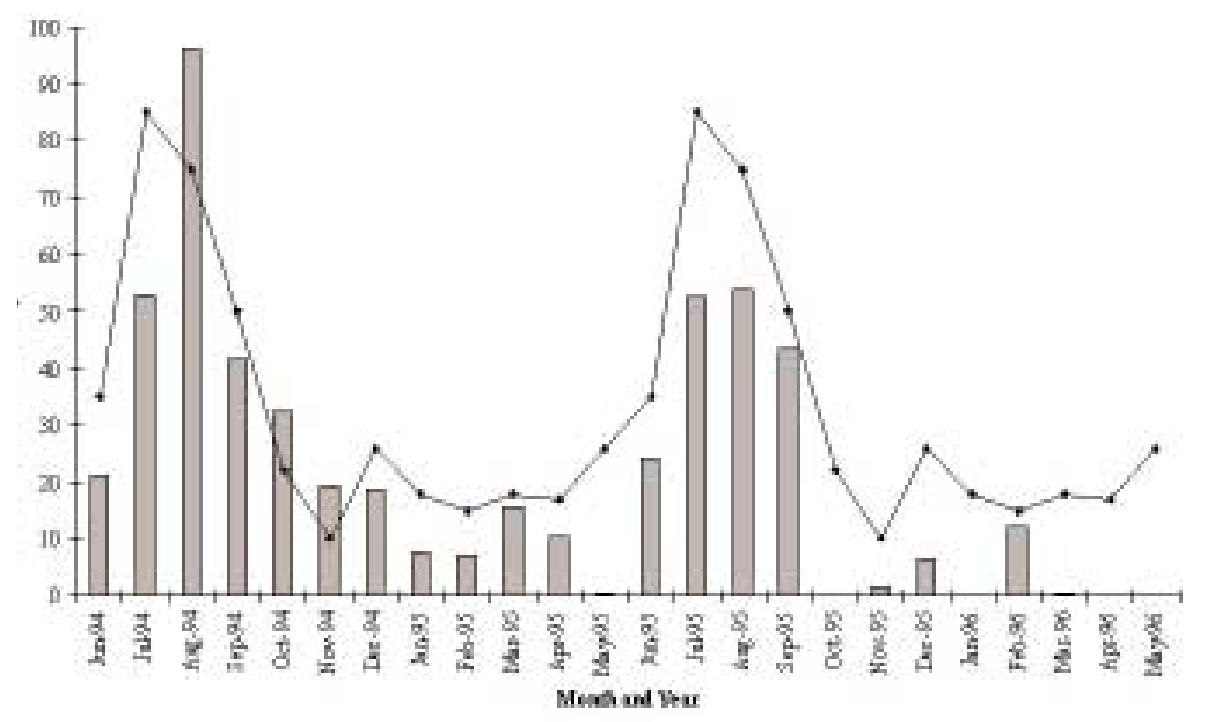

Clippings were obtained from plants intersecting the transect. Clippings consisted of terminal cladodes from the intersected plant (excluding buds) and were considered representative of portions cattle might naturally select based upon observation of rumen digesta in cannulated animals. Two paired clippings were collected from each of 25 plants. One of each pair was burned with a propane torch until all spines had been removed (BURN), but little or no singeing of the green plant material had occurred. The spines of the remaining clipping from each pair were left intact (UN). Burned and unburned clippings from each of 5 plants were combined to form 1 sampling unit, so that in total 5 samples were collected for BURN and UN. An additional sample was collected in a similar manner and used solely for determination of dry matter content.

\section{Chemical Analyses}

After collection, the sample collected for dry matter determination was immediately weighed, diced, and then dried in a forced air oven at $100^{\circ} \mathrm{C}$ for 24 hours. All remaining samples were diced and dried in a forced air oven at $40^{\circ} \mathrm{C}$ to a constant weight and ground through a Wiley mill to pass a $2 \mathrm{~mm}$ screen. Samples were analyzed for crude protein content by micro Kjehldahl methods (AOAC 1990) and for neutral detergent fiber content (Goering and Van Soest 1970). Samples were analyzed for ash content by ignition in a muffle furnace at $500^{\circ} \mathrm{C}$ for 6 hours

To determine ruminal degradability (as a measure of digestibility), equal amounts
Fig. 1. Precipitation (mm) by month from June 1994 through May 1996 (bars) and long term average monthly precipitation (line) at the Corona Range and Livestock Research Center. of each sample were composited within treatment. Three grams dry matter (DM) of composited material was placed into each of 8 Dacron bags $(10 \mathrm{~cm}$ X $20 \mathrm{~cm}, 44$ $\mathrm{mm}$ average pore size; Ankom Technology Corp., Fairport, N.Y.) per treatment. Four bags from each treatment were incubated in the rumen of each of 2 cannulated cows grazing native rangeland pastures at the Corona Research Center. Two bags were removed from each cow after 20 hours and 68 hours of incubation. Bags were frozen immediately to cease fermentation. Frozen bags were thawed at room temperature and rinsed with cool tap water until effluent was clear. Bags were then dried in a forced air oven $40^{\circ} \mathrm{C}$ to a constant weight to determine ruminal DM disappearance. A sample of the residue from each bag was ashed as previously described to determine organic matter (OM) disappearance.

Mineral composition was determined by an independent laboratory using ICP methodology (Agricultural Analytical Services Laboratory, University Park, Penn.). Minerals assayed were $\mathrm{P}, \mathrm{K}, \mathrm{Ca}$, $\mathrm{Mg}, \mathrm{Mn}, \mathrm{Cu}, \mathrm{Al}$, and $\mathrm{Zn}$. Crude protein and neutral detergent fiber content, mineral composition, and ruminal degradability were used as estimators of nutritive quality.

\section{Statistical Analysis}

Results of the dry matter determination were not subjected to statistical analysis since the sample was not replicated. The DM values obtained are therefore used for descriptive purposes only. Other data were analyzed by analysis of variance using the General Linear Models procedures of the Statistical Analysis System (SAS 1992) for a completely randomized design. Chemical composition data were analyzed with treatment (BURN or UN) as the only effects in the model. Ruminal dry matter and organic matter disappearance data were analyzed by time with cow and treatment as effects in the model. The shorter incubation is reflective of the rate of ruminal degradation, while the longer incubation describes potential extent of ruminal degradation.

\section{Results and Discussion}

Sample collection was conducted in June following 2 years of low precipitation (Fig. 1). Early summer represents a time when managerial decisions concerning drought management strategies are often implemented, and the sampling time was reflective of conditions in which cac- 
Table 1. Crude protein $(\mathrm{CP})$, neutral detergent fiber (NDF), organic matter (OM) and dry matter percentages for burned and unburned cholla cactus.

\begin{tabular}{|c|c|c|c|c|}
\hline Item & Unburned & Burned & $\mathrm{SE}^{\mathrm{a}}$ & $\mathrm{OSL}^{\mathrm{e}}$ \\
\hline & \multicolumn{4}{|c|}{$-\ldots(\%)-\ldots$} \\
\hline $\mathrm{CP}^{\mathrm{b}}$ & 13.0 & 13.6 & 0.7 & $P>0.59$ \\
\hline $\mathrm{NDF}^{\mathrm{b}}$ & 48.6 & 39.2 & 1.8 & $\mathrm{P}<0.005$ \\
\hline $\mathrm{OM}^{\mathrm{c}}$ & 82.4 & 81.0 & 0.4 & $\mathrm{P}<0.03$ \\
\hline $\mathrm{DM}^{\mathrm{d}}$ & 12.4 & 12.7 & -- & -- \\
\hline \multicolumn{5}{|c|}{$\begin{array}{l}n=5 \\
b \text { expressed as a percentage of OM } \\
c \text { expressed as a percentage of DM } \\
d \text { as fed basis } \\
\text { e observed significance level }\end{array}$} \\
\hline
\end{tabular}

tus feeding might be employed. Dry matter content of sampled cholla cactus averaged $12.5 \%$ (Table 1). Samples were collected 1 week following a $55 \mathrm{~mm}$ rainfall event, and increased soil moisture may have affected the moisture content of the cholla. Griffiths and Hare (1906) demonstrated up to a $9 \%$ increase in moisture content in prickly pear cactus sampled 1 year apart when the rainfall 3 months prior to sampling increased. Shoop et al. (1977) reported DM values for prickly pear ranging from $14.6 \%$ in June to $45.8 \%$ in February in Colorado. Dry matter content of cholla cactus in New Mexico was lowest (16\% to $20 \%)$ during the summer and increased to 38\% during February (Pieper et al. 1974). For several species of cactus, DM content ranged from $8 \%$ to $33.5 \%$ (Griffiths and Hare 1906). These authors reported an average DM content of $12 \%$ for walkingstick cholla, while Vinson (1911) reported a DM content of $22 \%$ and Vega-Villasante et al. (1997) reported $20 \%$ DM for walkingstick cholla and Opuntia cholla, respectively.

Although most reports agree that the DM content of cactus reaches a nadir in the summer months, moisture content is always relatively high. Feeding high moisture feeds may be beneficial in situations when the diet is of low quality (as in drought conditions). Pasha et al. (1994) found that as moisture content of the diet increased, ruminal passage rate increased. When available forages contain a high level of indigestible constituents, increasing passage rate may increase intake (Van Soest 1994). While intake may be impaired if the DM content of the diet is less than 25\% (Arnold 1962, Minson 1966) it is unlikely that enough of the diet would consist of cholla to achieve such an effect.

Cacti in general are slow growing perennials, and do not appear to exhibit dramatic fluctuations in nutrient quality with changing season (Shoop et al. 1977) when determined on a DM or OM basis. The fluctuation in moisture content may affect total DM intake, but does not affect the nutrient composition of the plant; therefore, temporal variation is probably not an important consideration when evaluating the nutritive quality of cholla for potential use as an emergency feedstuff within a given location, although large variation in quality may exist between species of cacti.

Crude protein content was not affected by spine removal in cholla cactus $(\mathrm{P}>0.5$; Table 1). These values are higher than most others reported for prickly pear cactus or cholla. Values for prickly pear cactus range from $5.9 \%$ to $6.5 \%$ (OM basis; Bath et al. 1995, NRC 1970, Shoop et al. 1977). The estimates from Bath et al. (1995) and NRC (1970) are composite values based on a large number of samples, and the value reported by Shoop et al. (1977) is similar to these composite estimates. In another study, Meyer and Brown (1985) reported a much higher crude protein level in prickly pear cactus of $14.1 \%$. This single value appears to be well outside the range of other reported values, and illustrates the potential variation among locations. Griffiths and Hare (1906) reported a range of CP values across several species of cacti at various locations in New Mexico, Arizona, and northern Mexico from $1.75 \%$ to $10.7 \%$, while Vinson (1911) reported a mean CP value for cholla of $7.5 \%$. More recently, Vega-Villasante (1997) observed CP content of 3.8\% in Opuntia cholla Weber, although this species is from Baja California. As with prickly pear, location and species may be important determinants of cholla quality. The crude protein levels observed in this study are at the high end of the range of reported values; however cholla cactus in general contains a higher amount of CP than prickly pear (Griffiths and Hare 1906, Wooten 1911) at a given location.

Mature beef cows in mid lactation (early summer in a spring calving herd) require between $8.5 \%$ and $10 \% \mathrm{CP}$ in the diet (NRC 1996). Cow diets sampled from a pasture near the study site at the Corona Range and Livestock Research Center were $6.3 \%$ CP 2 weeks before this study (Sawyer et al. 1997). Since the majority of reported values for prickly pear are below $7 \% \mathrm{CP}$, cattle that are maintained for long periods on dormant forage/prickly pear diets require protein supplementation (Hanselka and Paschal 1990). However, if $45 \%-55 \%$ of the diet could be supplied as cholla, cows could be maintained without protein supplements. If this proportion of cholla in the diet could not be achieved, the protein contribution of the cholla would still reduce the amount of additional supplement required to maintain cattle as compared to prickly pear.

Burning the spines off of cholla cactus reduced the NDF content of cholla $(\mathrm{P}<$. 01; Table 1). The NDF content for burned cholla is comparable to the $34.0 \% \mathrm{NDF}$ reported by Shoop et al. (1977) for burned prickly pear. This low value indicates that cholla contains a high amount of soluble carbohydrates and that it may be a source of rapidly fermentable energy. In situ disappearance of OM supports this premise (Table 2). Burned samples had a greater in

Table 2. Ruminal organic matter disappearance of burned and unburned cholla cactus after 20 hours or 68 hours of incubation.

\begin{tabular}{|c|c|c|c|c|}
\hline \multirow[b]{2}{*}{ Time } & \multicolumn{2}{|c|}{ OM Disappearance } & \multirow[b]{2}{*}{$\mathrm{SE}^{\mathrm{a}}$} & \multirow[b]{2}{*}{$\mathrm{OSL}^{\mathrm{b}}$} \\
\hline & Unburned & Burned & & \\
\hline (hours) & \multicolumn{3}{|c|}{ - - - - - $(\%)-\ldots$} & \\
\hline 20 & 66.3 & 77.3 & 2.4 & $\mathrm{P}<0.03$ \\
\hline 68 & 77.0 & 86.9 & 1.3 & $\mathrm{P}<0.005$ \\
\hline
\end{tabular}

$\mathrm{b}$ observed significance level

situ disappearance at 20 hours $(\mathrm{P}<0.05)$ as well as after 68 hours of incubation ( $\mathrm{P}$ $<0.05)$. This indicates that the rate and extent of ruminal degradation were enhanced by spine removal. When prickly pear cactus was incubated in situ for 48 hours, $66.4 \%$ of the DM disappeared (Shoop et al. 1977) while Meyer and Brown (1985) reported an IVDMD of $75.7 \%$ for prickly pear.

The ash content of cacti in general is variable and often quite high. The organic matter content of cholla was slightly reduced by burning $(\mathrm{P}<0.05$; Table 1$)$. Although this difference was statistically significant, it is of doubtful biological significance. Organic matter content of prickly pear ranges from $79.8 \%$ (Meyer and Brown 1985) to $86.5 \%$ (Shoop et al. 1977). Griffiths and Hare (1906) determined the OM of walkingstick cholla to be $78.9 \%$. In contrast, Opuntia cholla from Baja California was reported to have an ash content of only $5.1 \%$ (Vega-Villasante et al. 1997).

The high ash content of cacti is reflected by an accumulation of minerals. The content of selected minerals in burned and unburned cholla cactus is shown in Table 3. Spine removal decreased the amount of aluminum and zinc in cholla cactus $(\mathrm{P}<$ 0.07 ) but did not affect any other minerals examined. 
Table 3. Selected mineral composition of burned and unburned cholla cactus, and suggested mineral requirements and tolerances for beef cows.

\begin{tabular}{|c|c|c|c|c|c|c|}
\hline \multirow[b]{2}{*}{ Mineral (units) } & \multicolumn{2}{|c|}{ Treatment } & \multirow[b]{2}{*}{$\mathrm{SE}^{\mathrm{a}}$} & \multirow[b]{2}{*}{ OSL } & \multirow[b]{2}{*}{ Req. $^{b}$} & \multirow[b]{2}{*}{ Max. ${ }^{b}$} \\
\hline & Burned & $\overline{\text { Unburned }}$ & & & & \\
\hline Calcium (\%) & 4.85 & 4.56 & 0.13 & $\mathrm{P}>.14$ & $.20-.30$ & - \\
\hline Phosphorus (\%) & 0.17 & 0.16 & 0.01 & $\mathrm{P}>.50$ & $.18-.22$ & - \\
\hline Potassium (\%) & 2.19 & 2.08 & 0.13 & $\mathrm{P}>.56$ & $.6-.7$ & 3.0 \\
\hline Magnesium (\%) & 0.66 & 0.61 & 0.02 & $\mathrm{P}>.13$ & $.1-.2$ & .5 \\
\hline Manganese (ppm) & 73.0 & 75.20 & 4.78 & $\mathrm{P}>.75$ & $20-40$ & 1000 \\
\hline Copper (ppm) & 4.8 & 5.00 & 0.26 & $P>.60$ & $10-12$ & 100 \\
\hline Aluminum (ppm) & 91.8 & 115.60 & 8.15 & $\mathrm{P}=.07$ & - & 1000 \\
\hline Zinc (ppm) & 10.6 & 24.40 & 3.39 & $\mathrm{P}=02$ & $30-40$ & 500 \\
\hline
\end{tabular}

${ }^{n}=5$

adapted from NRC, 1996
The phosphorus contained in cholla approaches the dietary requirement of a beef cow (NRC 1996). Since dormant forage is generally low in $\mathrm{P}$, it is likely that additional $\mathrm{P}$ would need to be supplemented since cholla would not comprise the entire diet. Additionally, the high accumulation of calcium in the cactus creates a $\mathrm{Ca}: \mathrm{P}$ ratio of $29: 1$. Other authors have reported an accumulation of $\mathrm{Ca}$ by cacti (Shoop et al. 1977, Hanselka and Paschal 1990) with $\mathrm{Ca}: \mathrm{P}$ ratios potentially exceeding 20:1 (Griffiths and Hare 1906). The maximum acceptable ratio of $\mathrm{Ca}: \mathrm{P}$ in cattle diets is approximately 10:1 (NRC 1996), therefore additional $P$ supplementation would be necessary if large amounts of cholla are to be fed.

Potassium in cholla is well above animal requirements, but is below maximum tolerable levels, indicating that cholla is a good source of $\mathrm{K}$ in the diet. Potassium in dormant forage at this location was well below animal requirements $(0.29 \%$; Knox 1998), so that feeding cholla would improve K supplies. Magnesium in cholla is above the maximum tolerable level for beef cows; however, dormant forage at this location was very low in magnesium (0.05\%; Knox 1998). Additionally, high potassium levels reduce the absorption of $\mathrm{Mg}$, so that high $\mathrm{K}$ levels may offset high $\mathrm{Mg}$ levels. It is possible that the relatively high amounts of $\mathrm{K}$ and $\mathrm{Mg}$, coupled with the high moisture content of the cactus, could be responsible for the diarrheic condition often observed in animals fed cactus (Vinson 1911, Shoop et al. 1977, Hanselka and Paschal 1990), but it is doubtful that a toxic condition would be observed.

Manganese levels are well above required amounts, but well below maximum tolerable levels. Copper and zinc are both deficient in cholla to meet requirements for beef cows, so that additional supplementation of these minerals is warranted when feeding cholla cactus. Each of these minerals was found to be deficient in dormant forage at this location $(\mathrm{Mn}, 17$

\section{Conclusions}

Cholla cactus may be a suitable feedstuff for emergency situations such as drought. Cholla is a highly degradable source of energy and contains an adequate amount of crude protein to maintain productive animals with little or no additional protein supplementation. Burning to remove the spines from cholla improves the digestibility of the cactus without reducing protein content, and therefore may be preferred over chopping as a method of providing cholla to livestock.

The primary drawbacks to feeding cholla as an emergency feed are its excessive moisture and ash contents. The high mineral (ash) content of cholla may create problems such as diarrhea or excessive imbalances in mineral intake, especially calcium and phosphorus. These effects can be managed by supplementation with an appropriately formulated salt-mineral supplement to mediate deficiencies and imbalances.

High moisture content dictates that large amounts of cholla must be provided to achieve adequate levels of dry matter intake. This limitation may be offset if feeding begins before other forage resources (i.e., grasses) are completely exhausted, or if large and dense enough stands of cholla are available. Testimonial reports from Texas indicate that enough prickly pear can be burned in 20-30 minutes to feed 8-10 cows (Hanselka and Paschal 1990). If a similar provision rate can be attained with cholla, and labor is less expensive than alternative feed sources such as hay or grain, then feeding cholla may be cost effective.

Cholla cactus may be an acceptable alternative feedstuff, and could be a valuable drought/survival management tool for livestock producers, both to maintain livestock and to decrease the costs of drought management.

\section{Literature Cited} consumption is highest during the spring, cattle consume some amount of cactus throughout the year. Animals are frequently observed "checking" cholla for grazable portions. It is also common to see animals with pieces of cholla stuck on their muzzles, indicating that they have been attempting to browse the plants. These observations indicate that even without spine removal, cholla is a highly desirable browse species.

OAC. 1990. Official Methods of Analysis. (15th Edition). Association of Official Analytical Chemists, Arlington, Virg.

Arnold, G.W. 1962. Effects of pasture maturity on the diet of sheep. Aust. J. Agr. Res. 13:701-706.

Bath, D., J. Dunbar, J. King, S. Berry, and S. Olbrich. 1995. Byproducts and unusual feedstuffs. Feedstuffs Reference Issue. Vol. 67 no. 30.

Goering, H.D. and P.J. Van Soest. 1970. Forage fiber analyses. Agr. Handb. No. 379. USDA.

Griffiths, D. and R.F. Hare. 1906. Prickly pear and other cacti as food for stock II. Bull. No. 60, New Mexico College of Agr. and Mech. Arts, Mesilla Park, N.M. 
Hanselka C.W. and J.C. Paschal. 1990. Prickly pear cactus: an important rangeland resource. Texas Agric. Exp. Sta. Prog. Rept. 4859. Texas A\&M University. College Station, Tex. 141-143.

Knox, L.A. 1998. The response of beef cattle grazing native rangeland to management decisions. Master's Thesis, New Mexico State University, Las Cruces, N.M.

Krysl, L.J., M.L. Galyean, J.D. Wallace, F.T. McCollum, M.B. Judkins, M.E. Branine, and J.S. Caton. 1987. Cattle nutrition on blue grama rangeland in New Mexico. Agr. Exp. Sta.. Bull. 727. New Mexico State University, Las Cruces, N.M.

Meyer, M.W. and R.D. Brown. 1985. Seasonal trends in the chemical composition of ten range plants in South Texas. J. Range Manage. 38:154-157.

Minson D. J., 1966. The intake and nutritive value of fresh, frozen and dried Sorghum almum. Digitaria decumbens and Panicum maximum. J. Br. Grassl. Soc. 21:123-126.

NRC. 1970. Nutrient requirements of domestic animals: No. 4. Nutrient requirements of beef cattle, $4^{\text {th }}$ revised edition. Nat. Res. Coun. Washington D.C.
NRC. 1996. Nutrient requirements of domestic animals: Nutrient requirements of beef cattle, $7^{\text {th }}$ revised edition. Nat. Res. Coun., Washington D.C.

Pasha, T.N., E.C. Prigge, R.W. Russell, and W.B. Bryan. 1994. Influence of moisture content of forage diets on intake and digestion by sheep. J. Anim. Sci. 72:2455-2462.

Pieper R.D., K.H. Rea, and J.G. Fraser, 1974. Ecological characteristics of walkingstick cholla. New Mexico Agr. Exp. Sta. Bull. 623. New Mexico State Univ., Las Cruces, N.M.

SAS. 1992. SAS user's guide. SAS Institute, Inc. Cary, N.C.

Sawyer, J.E., L.A. Knox, G.B. Donart, and M.K. Petersen. 1997. Changes in dietary crude protein in cows grazing the Corona Livestock and Research Center. Proc. Cattle Growers Short Course. New Mexico State Univ., Las Cruces, N.M.

Shoop M.C., E.J. Alford, and H.F. Mayland. 1977. Plains pricklypear is a good forage for cattle. J. Range Manage. 29:4-8.

Thornber, J.J. 1911. Native cacti as emergency forage plants. Agr. Exp. Sta.. Bull. No. 67. Univ. of Arizona, Tucson, Ariz.
Ueckert D.N., J.L. Petersen, R.L. Potter, J.D. Whipple and M.W. Wagner. 1990. Range and sheep management for reducing pearmouth and other pricklypear-related health problems in sheep flocks. Texas Agr. Exp. Sta. Prog. Rept. 4782. Texas A\&M Univ., College Station, Tex. $40-41$.

Van Soest, P.J. 1994. Nutritional Ecology of the Ruminant, $2^{\text {nd }}$ Ed. Cornell University Press, Ithaca, N.Y.

Vega-Villasante, F., C.I. Chapa-Cortes, S. Rocha, H.L. Romero-Scmidt, and H. Nolasco. 1997. Nutritional quality and ecological impact of the use of Ferocactus peninsulae, Opuntia cholla, and other desert plants as cattle forage in the Baja California peninsula. J. Arid Environ. 35:499-509.

Vinson A.E., 1911. Nutritive value of cholla fruit. Agr. Exp. Sta.. Bull. No. 67. Univ. of Arizona, Tucson, Ariz.

Wooten E.O., 1911. Cacti as fodder for livestock. New Mexico Agr. Exp. Sta.. Bull. 78. New Mexico State Univ., Las Cruces, N.M. 